\title{
Homoki Andrea: Az iskolai szociális munkában rejlő lehetőségek a gyermekvédelmi szükségletorientáció alapelvének figyelembevételével
}

\section{Bevezetés}

Máté Zsolt (2015) iskolai szociális munkáról szóló átfogó tanulmányában ír arról, hogy hazánkban azon szakembereknek a köre, akik közvetlen tapasztalattal bírnak a segítő tevékenység ezen formájáról, igen szükre szabott: „,...alig félszáz iskolai szociális munkás dolgozik..." (Máté 2015: 77) az országban. A tanulmányban a szerző felvázolja, hogy az ezredfordulót követően az iskolai gyermekvédelemben dolgozó szakemberek aránya jelentősen lecsökkent, mind az alap-, mind a középfokú képzőintézményekben.

2016. január 1-jétől az 1997. évi XXXI. számú, A gyermekek védelméről és gyámügyi igazgatásról szóló törvény (Gyvt.) módosításának hatálybalépését követően a személyes gondoskodást nyújtó gyermekjóléti alapellátáshoz tartozó gyermekjóléti szolgáltatások keretében iskolai szociális munka biztosítható.

2016-ban az EMMI szociális ügyekért és társadalmi felzárkóztatásért felelős államtitkársága a család- és gyermekjóléti központok számára az óvodai-iskolai segítő tevékenységek fejlesztését célzó modellprogramok kidolgozását elösegítő pályázatot írt ki. A 2016-2018 közötti támogatási időszak zárását követően, a szolgáltatás biztosítására vonatkozó diszkrecionális jelleg normatívvá módosul. 2018 szeptemberétől az ország valamennyi családés gyermekjóléti központja kötelezően ellátandó szolgáltatásként látja el 1000 fő tanulónként 1 fő iskolai szociális munkás alkalmazásával a feladatot.

A gyermekek védelme - mely általános értelemben a harmadik generációs jogok körébe tartozó gyermeki jogokat összefoglaló univerzális szabálygyüjteményhez rendelt egyetemes gyermekvédelmi alapelvek szerinti társadalmi-intézményi-szülői hozzáállást feltételez - egy komplex, többszereplös folyamat.

Az ENSZ Gyermekjogi Egyezményében (1989) kinyilatkoztatott gyermekvédelmi alapelvekkel való egyetértésen túl - a szükségletorientáció, a diszkrimináció tilalma és a gyermek mindenekfelett álló érdeke -, a szakmai gyakorlatban az ,,ahány (iskola) ház, annyi szokás" elv érvényesül. A gyermek mindenekfelett álló érdeke és joga is, hogy öt egy elfogadó iskolai közeg formálja, egyéni és életkori sajátosságainak figyelembevételével, szükségletei szerint fejlessze. Egyéni szükségletei nem függetlenek életmódjától, azaz hétköznapi kultúrájától, melynek egyes elemeit szem előtt tartva és ezen elemek kapcsolódási pontjait rendszerezve végezhető team-munkában sikeresen az iskolai szociális munka.

A szakmai együttmüködést kezdeményező és koordináló professzionális segítő közremüködésével az iskola falain belül a szociális munka és a szociálpedagógia eszköztárával egyéni esetkezelés, illetve csoportmunka keretében megvalósítható minden iskolai szereplő külső, kapcsolati és belső erőforrásainak a fejlesztése, melynek hatására a gyermekek számára bejárható út, belátható tér kevésbé szükül be, az iskolai munka teret nyit/enged származástól és az átélt változások veszteségélményeitől függetlenül, illetve ezekkel együtt a továbbhaladásra, fejlődésre, továbbtanulásra. 
„Az iskolai szociális munka szolgáltatás a közoktatási intézményben biztositott, preventív jellegü segitö tevékenység, amely az iskoláskorú gyermekek és fiatalok képességeinek és lehetőségeinek legoptimálisabb kibontakoztatását támogatja szociális kapcsolataik, társadalmi integrációjuk javitásával.” (Bányai 2000:3)

Az iskolai segítségnyújtás professzionális müveléséhez, a gyermekvédelem komplexitásából adódóan célzott képzési, továbbképzési tartalmakra van szükség. Azon túl, hogy egyetérthetünk Máté Zsolt azon megállapításával, hogy a szociális munka alapszakokon és a szociálpedagógus-képzésben megjelenik az iskolai szociális munkával kapcsolatos ismeretek köre, néhány helyen a gyakorlati terephelyeken (iskolákban) a tapasztalatszerzés lehetősége is adott, azonban hiányosság a szolgáltatás tágabb társadalmi-szakmai körben való elhelyezése, szociális ágazaton túlmutató ágazati kapcsolódási pontok meghatározása, adott esetben a pedagógusképzésben való megjelenése.

A szociális munka Pécsi modelljének szemlélete szerint az „ökológiai szemléletü iskolai szociális munka" Rácz József (2009) - rendszerelméleti modellként definiálható, hiszen a gyermek szükségletorientált segítését egyfelől a gyermeki, másfelől a környezeti privációk csökkentésének, mérséklésének szolgálatában teszi. „,...nem a patológiákra helyezi a hangsúlyt, hanem a pozitiv viselkedésváltozásra, a képességekkel való felruházásra (empowerment) és a kompetenciaorientált fejlesztésekre, a reziliencia különbözö típusainak fejlesztésére, valamint az iskola érzékenyitésére mindezen eljárásokkal és szemléleti változásokkal kapcsolatban.” (Máté 2015: 88-89)

Az Alföld északi és déli régióinak LHH - kistérségekben élő halmozottan hátrányos helyzetben lévő gyermekek körében folytatott rezilienciavizsgálat (Homoki 2014b) eredményei szerint a 12 éven felüliek körében az iskola járul hozzá legkevésbé a rezilienciát előrejósló, azt elősegítő készségeik, képességeik fejlesztéséhez. Chicetti és Cohen (2006) meghatározásából kiindulva a rugalmas, reziliens gyermek a hosszan tartó nehézségek ellenére is képes boldogulni. Az atipikus eseteket vizsgáló „iskolai reziliencia” szemléletü kutatók (Ceglédi 2012; Pusztai 2004, 2011; Forray R. 2014; Csapó et al. 2014) reziliens tanulókkal kapcsolatos értelmezését szem előtt tartva, miszerint ők azok, akik kedvezőtlen családi körülményeik ellenére is jól teljesítenek az iskolában, fontos kihangsúlyozni, hogy ez az atipikus jelenség a reziliens diákok eseteiben csak igen alacsony százalékban (28\%) az iskola érdeme, a számos szempontból leszakadó térségekben.

Gyermekvédelmi szempontú rezilienciakutatásaink (Homoki, Czinderi et al. 2014, 2016, 2018) eredményei azt mutatják, hogy a reziliens tanulók boldogulási lehetőségeit serdülőkorban elsősorban az én-hatékonysághoz sorolható készségek és képességek növelik leginkább. Első helyen a legtöbb - boldogulást elősegítő - jellemzővel szignifikáns korrelációt mutató rezilienciatényező a pozitív önértékelés, az egészséges önbizalom jelenik meg, mint a 12 év feletti tanulók rezilienciáját elősegítő markáns tényező.

Az iskolai környezet azonban egy olyan összetevője a rezilienciának, mely tudatos alakításával a fenti eredménynél jóval hatékonyabban hozzájárulhatna az iskola a gyermek boldogulását elősegítő készségeinek, képességeinek fejlesztéséhez. Iskolai környezet elemeként értelmezésünkben térbeli, tárgyi, személyi erőforrások egyaránt megjelennek, ezek rendszerének minőségi müködése mind a gyermek tanulmányi sikerességére, mind interperszonális kapcsolatainak minőségére, mind intraperszonális jellemzőire (pl.: önértékelés) nagy hatást gyakorolhat - ezzel a reziliencia alakulása spirális jellegének 
ismeretében (Schofield, Beek 2005) - indukálhat fejlődést más rezilienciakomponensek területén is, növelve a gyermek boldogulási esélyeit (Homoki 2014).

Az iskolai környezetben kulcsszereplöként jelenhetnek meg a megfelelö képzettséggel és végzettséggel, személyiségükben alkalmas, rátermett iskolai szociális munkások. Fontos szerepük lehet a társszakmákkal történő együttmüködés keretében a fent említett ökológiai szemléletü modellek (pécsi modell) (Rácz, Máté, Szemelyácz 2009), illetve a rendszerelméleti hátterü gyermekvédelmi rezilienciamodell (Homoki 2014) szemléletének, továbbá az ökológiai elméleten alapuló oktatásszociológiai kutatások eredményeinek (Forray R. et al. 2004, 2013, 2014) pedagógusok körében történő ismertetése, annak érdekében, hogy a szakmai team hatékonyan tudjon segíteni.

Pedagógusok segítése céljából ezen információk rendszerszemléleti megközelítésben történő átadására már az alapképzésekben, majd szakirányú továbbképzésekben, posztgraduális képzéseken is sor kerülhet. Számos olyan jelenség fordul elő a gyermekek iskolai életében, melyek szocioökonómiai háttértényezői összetettek, ezek rendszerszemléletü elemzésével válhatnak képessé az iskolai gyermekvédelemben dolgozók a gyermekek szükségleteit célzó, adekvát válaszok szolgáltatására.

„A pedagógusoknak képesnek kell lenniük felismerni és lehetőség szerint megelőzni a gyermekeket iskolai közegben érő destruktív hatásokat, ártalmakat, ideértve a mobbing és bullying jelenséget is. A már kialakult problémák kezelésében az iskolában dolgozó segítő szakembereknek, iskolapszichológusoknak, iskolai szociális szakembereknek van elsődleges szerepe (ahol egyáltalán vannak kellő számban és időtartamban alkalmazott segítő szakemberek), ám e problémák rendszerint csak a pedagógusok együttmüködésével, team munkában orvosolhatóak kellő hatásossággal. Ez újabb speciális tudásokat és képességeket követel meg a pedagógusoktól.” (Soós 2017: 26 ) A szerző írásában a fenti jelenségeken túl utal az iskolák gyermekvédelmi jelzőrendszerben betöltött funkciójára is, melynek keretében a pedagógusoknak a gyermekbántalmazás (elhanyagolás, testi, lelki, szexuális abúzus, kizsákmányolás) jeleit felismerve képesnek kell lenniük a segítő beavatkozás, intervenció megtételére. Ennek érdekében a szakjához kapcsolódó pszichológiai és szociológiai ismeretkörökön túl, a család és gyermek jólétének biztosítását elősegítő szociálpolitikai és szociális-gyermekvédelmi ismeretekkel is szükséges rendelkeznie.

Napjaink pedagógusképzési gyakorlatának feltáró kutatását a HERA Egyesület Gyermekvédelem-Szociálpedagógia Szakosztálya végezte el átfogóan 2014-ben. Eredményeik szerint ezek az ismeretkörök tantárgyi szinteken megjelennek a pedagógusképzések mintatanterveiben, „...ugyanakkor elvétve van lehetőség intézményi gyakorlatra/terepgyakorlatra..." (Gönczi 2014: 591, idézi Soós 2017: 28).

A kutatás másik fontos megállapítása, hogy a képzésben nagyobb teret kellene kapnia a „szülőkkel történő hatékonyabb együttműködési formák kialakításának, megszervezésének, tanításának, a velük történő eredményesebb kommunikációs és különböző problémamegoldó eljárások begyakoroltatásának a képzési folyamatban" (Gönczi 2014: 593, idézi Soós 2017: 37). 


\section{A társadalmi életképességet gátló jelenségek háttere az ifjúságkutatások tükrében}

A tanulmány előző fejezetében röviden áttekintettük az iskolai szociálismunka-szolgáltatás biztosításának alakulását az elmúlt néhány év rendelkezései szerint, melyek értelmében 2018 őszétöl a pedagógusokkal együttmüködésben a család- és gyermekjóléti központok iskolai szociális munkát biztosítanak tanulói létszám függvényében. Az iskolai szociális munkával hatékonyabban elősegíthető a gyermek boldogulási képességeinek fejlesztésében jelentős szerepet játszó pozitív iskolai környezet kialakítása, mellyel a gyermeki reziliencia nagymértékben elősegíthető.

A továbbiakban a hazai ifjúságkutatások eredményeinek tükrében azokról a gátló társadalmi jelenségekröl írunk, melyek tünetei megjelennek az iskolákban is, és a sikeres fiatal felnőttkort, a társadalmi ,életképességet” akadályozhatják idő előtti iskolaelhagyást, iskolai lemorzsolódást indukálva, minek következtében az érintett fiatalok munkaerőpiaci integrációja is alacsonyabb szinten valósulhat meg.

„A 2012-es ifjúsági adatfelvételi hullám eredményei között a foglalkoztatáshoz és munkaerőpiachoz kapcsolódó kutatási adatok egyértelműen rajzolják ki azt a képet, miszerint a munkapiaci pozíciók tekintetében kedvezőtlen helyzetben lévő fiatalokat halmozott hátrányok terhelik, amelyek a kutatás által meghatározott empirikus dimenziókban mindenekelőtt a munkahely átlagosnál gyakoribb elvesztésében, az átlagosnál hosszabb ideig tartó és nehezebb elhelyezkedésben, illetve a személyes munkapiaci pozíciók alakulását tekintve a pesszimista várakozások túlsúlyában jelennek meg." (Gazsó 2013: 149)

A 21. század első évtizedében folytatott ifjúságkutatások eredményeit bemutató Arctalan (?) nemzedék - Ifjúság 2000-2010 című tanulmánykötetben (szerk.: Bauer-Szabó 2011) Somlai Péter a hátrányos helyzetü családokban élő gyermekek iskolai előmenetelének nehézségein túl, a családi nevelés változására is ráirányítja a figyelmet. „A mai szülők a régebbieknél kevésbé tudják ellenőrizni gyerekeik életét. Kevesebbet tudnak például arról, hogy hol, kivel és hogyan töltik szabadidejüket. Pedig a fiatalok közül sokan élnek hosszabb ideig együtt, közös lakásban szüleikkel. De az évek múlásával a szülök egyre inkább elfogadják gyerekeik autonómiáját." (Somlai 2012: 32) A fiatalok döntési önállósága kiterjedt a hétköznapi életük tevékenységrendszere szintjén a fogyasztásra, szabadidő-eltöltésre, társas kapcsolatok alakítására, korai és mélyebb elköteleződést sok esetben nélkülöző párválasztásokra, késői házasságkötésre. Az életmódjukat meghatározó új, individualista értékrend a társas támogató háló átstrukturálódását eredményezi: „...módosultak a személyközi kapcsolatok. A mobiltelefon és az internet korában egyre sủrübb lesz a fiatalok kapcsolathálózata. De közben kerülik a tartós elköteleződést, az olyan kötelékeket, amelyek felbomlaszthatják énjük mélyebb szerkezeteit." (Du Bois 1998, idézi Somlai 2011: 33)

„A szabadidő-eltöltés módja jórészt egyéni aktivitást tükröz, a társaság és a hagyományos közösségi tér használatának hiánya látszódik." (Bauer 2011: 246)

Családi, kortárs és iskolai megtartó és támogató kötelékek nélkül a fiatalok életcéljai és jövőképe kevéssé kiforrott, sok esetben az élettervezés alapjai hiányoznak, mely jellemzők szintén a sikertelen társadalmi integrációt, munkapiaci érvényesülést vetítik előre, a rezilienciatényezők összefüggésrendszerének ismeretében gyakran negatív egészségmagatartás, deviációs folyamatok indulhatnak be, így a gyermek az egyéni fejlődés spirálja helyett a „lecsúszás” útján haladhat.

„A kockázati magatartások, melyeknek többsége például a dohányzás vagy alkoholfogyasztás, a felnőttség szimbólumaként jelennek meg a fiatalok számára, a biológiai felnőtté váláshoz igazodva kerülnek szélesebb körben kipróbálásra. Ez a jelenség mutatkozik meg a 
táplálkozási szokásokban, az egyre korábban elkezdett, nem biztonságos szexuális aktivitásban és egyes veszélyeztető szabadidős tevékenységek kipróbálásában. A fiatal korosztályok egyes hátrányos helyzetü csoportjaiban, például a nehéz fizikai vagy monoton munkát végző, a veszélyes munkakörülmények között dolgozó, a kedvezőtlen körülmények között élö, illetve munkanélküli fiatalok körében a káros, önsorsrontó tendenciák fokozottan érvényesülnek és termelődnek újjá." (Susánszky 2011: 152)

Fábián Róbert kutatási adatai (2011) a fentiekkel ellentétben nem igazolják az összefüggést a szülő sátusza, anyagi helyzete és a destruktív egészségmagatartás között.

A korábban elemzett kutatási eredményeink ismeretében ezek hátterében sokkal inkább állhatnak a szülö-gyermek, iskolai aktorok - tanuló kapcsolati zavarai, időhiányból fakadó „szer”etethiány, melyet a fiatal egészségkárosító szerekkel pótol.

„Az utóbbi időben a fiatalok »gyors hétvégi lerészegedésének « jelenségét tapasztalják az addiktológusok, pszichológusok. Arra hívják fel a figyelmet, hogy az alkoholfogyasztás sok esetben már nemcsak a társasági élet keretét adja, hanem a hétvégi gyors kábulat előidézését szolgálja. Egyre inkább elveszíti a közösségi élethez kötődő szerepét, és a tudatállapot megváltoztatását szolgáló eszközzé vált.” (Fábián 2011: 217)

A fentiekben áttekintett ifjúságkutatási eredmények is rámutatnak az iskolás éveikben járó gyermekeket és fiatalokat célzó iskolai szociális munka sokszínüségére. Az elemzett adatokból arra is következtethetünk, hogy a gyermek egyéni boldogulási esélyeinek növelése, majdani munkapiaci integrációja, rezilienciájának elősegítése a szűkebb (családi és baráti kapcsolatok) és tágabb (iskolai, szabadidős) helyi közösségeinek fejlesztése nélkül hatékonyan nem valósítható meg. A tanulókat elfogadó és befogadó, jövőképére, életcéljaira nézve inspiráló közösségek kialakításában, formálásában és fejlesztésében a fent érintett szakmaközi együttmüködés keretében az iskolai szociális munkás szakmaisága meghatározó lehet.

\section{Iskolai szociális munkások kezdeti nehézségei, dilemmái, hatékonysága, eredményeik, jövőképük egy kutatás tükrében}

Tanulmányunk további részében a 2015 öszén kvalitatív módszerrel folytatott kutatásunk eredményei alapján mutatjuk be a (kezdő) „iskolai szociális munkások” első éveinek gyakorlati tapasztalatait, dilemmáit, nehézségeit, sikereit: munkájuk mérhető hatásait.

A kutatásunk szereplöi a Dél-Alföld régió sarkadi $\left(\mathrm{LHH}^{1}\right)$ kistérségében 11 településen iskolai szociális munkásként, illetve egy-két helyen gyermek- és ifjúságvédelmi felelősként/koordinátorként dolgozó pedagógusok $(\mathrm{N}=9)$ voltak. A körükben folytatott mélyinterjúk adatainak elemzésével vizsgáltuk a gyerekesélyek növelésére irányuló iskolai szociális munka eredményességét a professzionális segítő szemüvegén át, az alábbi kutatási kérdéseinkre választ keresve:

- Mit tehet/tehetett az iskolai szociális munkás helyi szinten?

- Hogyan ágyazódott be a helyi közösségbe?

- Hogyan hasznositotta, alkalmazta általános segitői professzióját, az iskola világában sikerei és nehézségei függvényében?

\footnotetext{
${ }^{1}$ A leghátrányosabb helyzetben lévő kistelepülések együttese (társadalmi, gazdasági és infrastrukturális mutatók alapján).
} 
Az interjú módszerével végzett adatgyüjtésünk elemzésekor interjúalanyainkat az interjúk során elhangzottak alapján az alábbi „fantázianevekkel” láttuk el:

„,magabiztos”; „,szuperhős”; „,bizonytalankodó”; „harcos”; lelkiismeretes”; „színes egyéniség”; ,, sokoldalu”,; „távolságtartó”; ,rátermett”.

A munkához való viszonyulás, a feladatvégzés során tanúsított helytállás önreflexiója mentén választott elnevezések is sugallhatják azt a sokféleséget, mellyel a segítő tevékenységet a személyiségével megvalósító iskolai szociális munkás dolgozhat.

\section{Mit tehet/tehetett... az iskolai szociális munkás? Fontos-e, hogy legyen?}

A válaszadóink egyöntetüen hangot adtak annak a meggyőződésüknek, hogy a térségben 2013 óta folytatott iskolai szociális munka hiánypótló tevékenység, abban az értelemben, hogy az iskolai gyermek- és családvédelem, gyermekvédelmi prevenciós feladatok megoldhatatlanná válnak a pedagógusok leterheltségének, erőforrásaiknak ismeretében.

„Sok olyan hátrányos helyzetü, illetve elhanyagolt gyerek van az iskolában, akikkel a pedagógusnak már nincs kapacitása foglalkozni, otthon pedig nem foglalkoznak vele. És ezt a fajta törödést sok esetben tölünk kapják meg a gyerekek."

„Sok órájuk van, le vannak terhelve, nincs úgy ideje odafigyelni rá, nem is lehet... hogy egyébként a gyerek beszél és a tanár vissza se tudná mondani, hogy miröl beszélt a gyerek, mert pontosan nem oda figyel rá, már a következö feladatra kell koncentrálnia." (magabiztos)

„,...vegyes érzelmeim vannak ezzel kapcsolatban, az alsós tanitókat nézem, ott más a helyzet, ök jobban ismerik a szülöket, a gyerekeket, közelebb vannak még a családhoz... de jobb az, ha dolgozik a családokkal a kivülálló szakember, mert ha olyan jellegü probléma van, akkor nyilván azt úgyis megosztjuk az osztályfönökkel és akkor próbáljuk meg együtt megoldani."

„Nagyon fontosnak tartom, hogy ott lehessen a szociális munkás az iskolában, mert nem a pedagógus feladata lenne az, hogy hatósági intézkedéshez kapcsolódó dolgokat intézzen, nem biztos, hogy kompetens. "(távolságtartó)

„...a gyámhivatalokba irták a védelembe vételi javaslatokat, ez nem a pedagógus feladata lenne, hanem a szociális munkásé... nem lehet ezt tanitás mellett csinálni, el lehet látni, mert mindent meg lehet csinálni, ki mennyit áldoz fel a kis szabadidejéböl, mert ez nincs megfizetve. Nem biztos, hogy erre vágyik egy pedagógus, általában ezt nem akarja végezni, mert ha ezt tökéletesen, de lelkiismerettel akarja csinálni, rengeteget kell, hogy tegyen egy problémásabb közösségben." (lelkiismeretes)

„,...igen is kell a gyerekeknek, valaki, akihez bekopoghat néha... akár egy segitö beszélgetésre." (rátermett)

„...egy teljesen más szakemberre, mint mondjuk a szociális szakemberekre szükség van. Hiszen nagyon sok konfliktus van a mai világban, és a gyerekek nem tudnak mit kezdeni ezzel a rengeteg információval, az internet adta lehetöségekkel, a tévé, a tévé adta 
dolgokkal ezeket nagyon nehezen dolgozzák föl. És akkor ott vannak még a családi problémák, amikor behozzák a gyerekek..." (bizonytalankodó)

„A személyes jelenlétét a segitönek, akihez bizalommal fordulhat a gyermek családi problémái miatt is, nagyon fontosnak tartom. Föleg, hogy a mi kis településeinken egyáltalán nem érhetö el a pszichológus." (szuperhös)

A fenti részletekböl kirajzolódnak azok a tevékenységek és célcsoportok is, melyekkel a válaszadók a pedagógusok mellett, szükség esetén velük együtt foglalkoznak az iskolákban: segítő beszélgetés, családi problémák, hátrányos helyzetű gyermekekkel való foglalkozás, életvezetési tanácsadás.

\section{Az iskolai szociális munkás beágyazódása az iskola világába mint helyi közösségbe?}

A 21. század első évtizedében, az iskolai szociális munka létjogosultságát, fogadtatását vizsgáló hazai kutatások eredményei ${ }^{2}$ szerint függetlenül településtípustól, az oktatás szintjétől és az iskola életvilágától, a pedagógusok kezdeti viszonyulása a szociális munka iskolán belüli megvalósításához feszültségekkel terhelt volt.

Jellemző volt a „,kenyérféltö attitüd” körükben, és a kutatások feltárták a társszakma képviselöinek kompetenciáival összefüggésben a félinformációk, információhiány távolságnövelő hatását is. Ezen kutatási eredmények nem tértek ki arra, hogy a kezdeti fogadtatást követően sikerült-e beilleszkednie a segítö foglalkozású szakembernek a pedagógustársadalomba, avagy végleg ,számkivetett” maradt?

Interjúinkban azon túl, hogy rákérdeztünk a fogadtatásra, azt is mértük, hogy a hároméves projektciklus alatt dolgozó szociális munkásoknak hogyan sikerült beágyazódniuk az oktatási rendszer vizsgált intézményeinek tanári-tanulói-szülői közösségeibe:

„Mivel a szülőfalum és én is oda jártam iskolába, és ismerem a pedagógusokat... és mind tanitott engem és ismernek, ezért ott igazából semmi probléma nem volt. Örültek neki, hogy oda kerültem, nem volt ellenségeskedés. Viszont a másik két iskola közül az egyikben azért észrevettem egy kis féltékenységet, mert amikor oda kimentem, akkor a gyerekek mindig ott voltak körülöttem. Menjünk játszani - kérleltek, ölelgettek, fogták a kezem. Én voltam a központban nem a tanitó néni." (magabiztos)

„....nekem volt egy kis elönyöm, mert az általános iskolában ott tanultam, illetve gimnáziumban is ott tanultam, úgyhogy sok pedagógust ismertem. Emlékeztek rám, tehát nem is voltam olyan rossz gyerek, úgyhogy ez abszolút jó irányba, jó irányú volt ez a kapcsolat, és ez ugyanabba az irányba folytatódott is. Tulajdonképpen nekem ezért tennem nem is nagyon kellett, csak tartanom kellett a szintet, meg segitenem kellett. Úgyhogy ez nekem különösebb eröfeszitésembe nem került." (rátermett)

„, Kaptam hideget, meleget... mondom, hogy mind a kettöböl kaptam. De ezek érzések voltak, olyan metakommunikáció (tekintet, elfordulás...) ezt érzi az ember, ha fenntartással fogadják, de olyan konkrét ellenállásba, face to face, sose ütköztem, sehol." (bizonytalankodó)

\footnotetext{
${ }^{2}$ Marosi, Tóth (2002); Makai (2003); Homoki (2012).
} 
„,...amikor ugye megkaptam azt, hogy a gyerekek engem jobban szeretnek, könnyü nekem, én nem osztályozok, értékelek, azért az egy csöppet rosszulesett. Meg sorolták, hogy az elödöm mit hogy csinált." (lelkiismeretes)

„Mindenki jól fogadott, mindenki örült nekem.” (sokoldalú)

„Ök akartak engem, én meg akartam őket.” (szuperhős)

„, Volt olyan szülö, tudod ez a nagyon lelkiismeretes, és igazából nem azért foglalkoztam a gyerekkel, mert mondjuk hátrányos helyzetü vagy halmozottan hátrányos helyzetü, mert nem. [...] Viszont van, volt az a fajta szülö is, aki nyilván problémás gyerek és akkor behivtam a szülöt, hogy nagy gondok vannak és »az ö gyereke biztos, hogy nem, mert csak beleviszik a rosszba, és egy áldott jó gyerek« és volt ez a faja szülö is. [...] És volt, akivel nehéz volt. Viszont volt olyan szülö is, aki teljesen elzárkózott ettöl. Tehát mondta, hogy öt aztán nem érdekli, mi van a gyerekkel, öt nem érdekli, hogy probléma van és egyébként is hagyjuk békén, kész." (magabiztos)

„,... a saját kis falumban nagyon-nagyon hamar elfogadtak a gyerekek, mivel ismertek ott is. Sokkal könnyebb dolgom volt, a többi kis településen többségében könnyen elfogadtak."

„Mondtam, hogy ki vagyok, mi vagyok, a bemutatkozáskor a szülöi közösség abszolút mindenhol pozitívan fogadott..." (lelkiismeretes)

„A településen nyitottak voltak a szülök. Ök egyböl szívesen fogadtak. Itt több is a hátrányos helyzetü, nem félnek segitséget kérni, nem szégyellik, hogy ez van, hanem próbálnak mindent megtenni, meg minden. Tehát hogyha nem szégyellik azt, hogy »nem tudom, hogyan kell ezt elintézni«, akkor jönnek segítséget kérni. Úgyhogy nyitottak az emberek. Úgy a szülök, gyerekek, mindenki." (sokoldalú)

„A gyerekek egyböl örültek, új ember van itt, meddig lesz itt, [...] úúúú ilyen sokáig... itt lesz." (bizonytalankodó)

„Nagyon hamar befogadtak a gyerekek. Elsö héten már, egyböl, pedig nem ismertek elötte, de szerintem az nagyon fontos volt nekik, hogy újak vagyunk és igazából fiatalok, más korosztály, mint a kistelepülés pedagógusai, fiatalok vagyunk és "más mindenre" nyitottak, más a szemlélet." (színes egyéniség)

„Általános iskolában meg a gimiben is bemutatkozással kezdtem, tehát amikor odakerültem, mondtam, hogy volt ilyen power point diákoknak is és minden osztályba bementem külön-külön. [...] Elmondtam, hogy ez és ez a helyzet, beszéltem arról, hogy mivel lehet hozzám fordulni, miket csinálhatunk együtt, bátran keressenek. Általános iskolában ez úgy müködött, hogy akkor még hatodikosok, talán hatodikosok. Az volt a lényeg, hogy biztos nagyon szimpatizáltak velem, mert ök onnantól kezdve majdnem minden szünetben ott voltak az irodámban. [...] És akkor 5-6-an jöttek és mondták, hogy ez és ez a problémájuk." (rátermett)

„Nekem szerencsém volt, de volt olyan kollegám, mármint aki iskolai szociális munkás, hogy akit úgy fogadtak, hogy... na jó...!? ez nem kell ide. Nálam is elöször így volt, hogy mondták, hogy nincs szükség erre. Szemembe mondták, hogy ez felesleges." (távolságtartó) 
„,Nagyon nehezen fogadtak, féltek, húzták a szájukat... »Megint csak egy ember, aki figyel minket! « Tehát ök azt hitték, hogy én valami ellenör leszek, aki a munkájuk minőségét nézi. Támadásnak vették a jelenlétemet. ...mikor kezdtek rájönni, hogy könnyitek rajtuk, mert ez és ez is az én feladatköröm lenne, leadhatnak nekem dolgokat, és más esetekben pedig együtt tudunk dolgozni, szivesen segitek, akkor már nyugodtabbak lettek. Úgy gondolom, hogy a kezdeti nehézségek ellenére nagyon jó kapcsolat lett, befogadtak teljesen, és utána bármilyen problémával, egyböl szóltak, jeleztek, hogy ha ezt tapasztalták a gyereken vagy valami, úgyhogy szerintem köztünk nagyon jól müködött a kommunikáció, és sikerült kialakitani az együttmüködést." (harcos)

A szülök??!! [...] ááááá, semmilyen kapcsolatba nem léptek velem. Tudták, hogy ott vagyok, ennyi. Ott nem is müködik, ott a családsegítönek van nagyobb elfogadottsága. Idegentöl félnek az emberek segítséget kérni. Szégyellik, ha gond van, [...] inkább vagy nem csinálnak semmit, vagy ha csinálnak, akkor átmennek más településre, hogy ne derüljön ki, hogy ez van velük. Ott így müködik az egész, ez az igazság. Nem is nagyon volt iskoláskorú gyerek, akivel dolgoztam volna egyénibe... egy gyerekkel se volt olyan dolgom, hogy mondjuk segitőbeszélgetés..." (távolságtartó)

A fenti részletekből is kiolvasható, hogy a segítő szakember beilleszkedése, elfogadottsága is több tényezőtől függhet.

Pozitív irányban mozdíthatja elő az elfogadást, amennyiben a helyi társadalom lokálpatrióta értelmiségéről van szó, azaz egy korábban már ismert, „nem idegen” személy jelenik meg iskolai szociális munkásként. Jellemzően azonban ezek a kistelepülések elöregedőek, melyekből az első generációs értelmiségi réteghez tartozók nagy arányban elvándorolnak, ezért sok esetben más településről származó ingázó segítők jelennek meg, akik - időnként „csak meg-” - érzik az ellenállást, a távolságtartást. Kutatásunknak ezen eredménye hozzájárulhat ahhoz, hogy a szociális munkások képzése során a terepgyakorlati helyszínek közé bekerülhessenek az iskolák, ezzel a társszakmák közötti társadalmi távolság

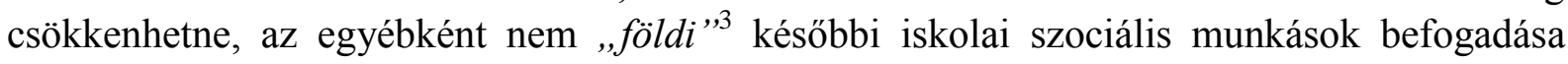
feszültségmentesebb lehetne.

A szociális munka elméletének alaptézise, hogy a szociális munkás egyik legfontosabb értéke a saját személyisége. Az interjúrészletekből az is érzékelhető, hogy a segítő társas készségei, nyitottsága, lendületessége, fiatalos vitalitása, kitartása, kreativitása, tudatossága, mind a kezdetben ellenérzésekkel, adott esetben félelemmel, tartással fogadó pedagógusok, mind a szülők és az újdonságra többnyire örömmel nyitott gyermekek közösségében fontos tényező az ön- és a segítségnyújtás elfogadtatása érdekében.

A válaszadók többségénél pozitívumként jelenik meg, hogy szinte azonnal elfogadták, illetve mindannyian sikeresen megtalálták helyüket és töltötték be szerepüket az iskola intézményének szervezeti és közösségi struktúrájában, azonban az is jellemző volt, hogy a legmarkánsabb ellenállást nem a szülők és a gyermekek oldaláról tapasztalták a kezdő iskolai szociális munkások, hanem a társszakma képviselőitől.

A szakmai együttmüködési készség és hajlandóság célzott, tervezett fejlesztésével továbbképzéseken, szakmai mühelyek keretében, adott esetben a település gyermekvédelmi

\footnotetext{
${ }^{3}$ A származási családját tekintve nem tősgyökeres községi lakos (a Szerzö).
} 
jelzőrendszerének éves szakmai megbeszélésén fejleszthető a felek „egy asztalhoz ültetésével”, közös feladatcsoportban való aktív részvételi lehetőségek biztosításával.

\section{Professzió, hétköznapi eredmények, sikerek a nehézségek dacára is...}

Nehézségként fogalmazták meg a közömbös, nem együttmüködö, időnként negatív hozzáállást, a helyi gyermekvédelmi szakemberek együttmüködésének hiányát, mely munkavégzésük közben hátráltatta őket.

„...nyilván ha nem olyan a hozzáállás és nem segitőkészek. Az is fontos, hogy maga a szociális ellátórendszer milyen az adott településen, mennyire tudnak teamben dolgozni, kivel tud teamben dolgozni az ember, ez meghatározza, hogy mennyi a sikerélményed! Mert azért elég hamar ki lehet égni, meg bele lehet fásulni." (magabiztos)

„Az nehézség, ha olyanok a kollégák, hogy hogy nem hagynak élni, az neheziti a munkát... ha nem hagyják érvényesülni, vagy nem kap lehetöséget [...] ha be akarsz menni az osztályhoz és nem engedik. Volt olyan, hogy a vezetöség... nem örült, hogy én elkérem a diákokat egy-egy tesi óráról és a fiatal tanárnak mondták, hogy ne engedje el a gyereket, mikor én elkérem... az egyénisnek hiába mondod, hogy neked 15 órakor van időd, mikor ö vége az óráinak délután és már 13 órakor hazamehet, vissza nem fog jönni... nem foglalkozik az idöponttal." (bizonytalankodó)

Többnyire azonban, akár a kezdeti fogadtatás nehézkessége ellenére is, érzékelték a válaszadó iskolai szociális munkások munkájuk hatékonyságát, konkrét sikereikről, eredményességük jellemzőiről árulkodnak az alábbi idézetek:

„,Volt olyan gyerek, aki arra játszott, hogy tudta nagyon jól, hogy ha rosszul viselkedik, akkor küldik hozzám... és erre rá is játszott. Ezt is sikerült leépítsük, mert elmagyaráztam neki azt, hogy nem kell felhívni magadra a figyelmet, nem kell rossznak lenni. Odajössz, beszélgetünk. Éppen ha órád van, de nagyon fontosnak érzed a találkozást, inkább kikérlek róla, nem probléma. Volt ilyen az elején, de ezzel megküzdöttünk." (lelkiismeretes)

„...volt olyan eset és ez már azért egy elég durva és elég súlyos eset, amikor a kisfiú azt mondta, hogy hazamegyek és felakasztom magam... alsós volt a kisfiú. Segítö beszélgetésekbe kezdtünk, konzultáltunk pszichológussal, szülökkel, szakemberekhez irányitottuk öket... fontos volt, hogy a gyerekböl kirobbant az érzelmi dugó... és volt kire árassza a fájdalmát, jó, hogy ott voltunk... az ilyesmit mindig komolyan kell venni, akármilyen kicsi..., söt, serdülöknél is." (szuperhös)

„Egy alsós kisfiúnak valamit odaszólt valaki, de igazából én nem gondolnám, hogy olyan durva volt, tehát semmi trágár kifejezés nem volt benne, csak ez a szokásos kis csipkelödés, ami a gyerekek között szokott lenni. És egyszerüen annyira felhúzta magát rajta, hogy röptében nekiugrott a másiknak. És pont tehát ott álltam kint a folyosón, láttam meg hallottam ezt az egészet, én gyorsan lefogtam a kisfiút, akkor volt elsös, és ahogy fogtam így a kis kezét vagy hát itt a vállát, hogy ne szaladjon neki a másiknak és orditott, hogy »engedj el, engedj el, utállak téged is, meg mindenkit«, meg olyan trágár dolgokat mondott, meg kiabált, hogy [...] csak kerekedett a szemem. Fogtam a vállát... »nem engedlek el, nyugodj már meg, most mi a baj, miért vagy ilyen dühös? « »Engedj 
el, engedj el!« - kiabálta, majd puff, bokán rúgott. »Úuhh - mondom -, köszi, ez jólesett! « Na és akkor volt az, hogy fogtam a kis kezét és kimentünk a csaphoz és megkértem, hogy mossunk kezet, majd arcot. Elöttem egy pedagógus belecsúszott, hogy bevitte a gyereket a vécébe és a csap alá nyomta a fejét. És akkor láttam azt, hogy a többi gyerek, hogy nézett rá, meg mondták a társukra, hogy hogy idegbeteg... megvolt a megbélyegzés, én erre nagyon figyeltem, hogy azt mondtam neki, hogy na gyere és akkor most kezet mosunk, és én is mostam a kezemet vele együtt, a csap alatt. És vizezzük be a kezünket, most mossuk meg az arcunkat, most veszünk egy nagy levegöt, kifújjuk. És ezt így nem tudom, sokszor, nagyon sokszor végigcsináltuk, mire megnyugodott. És akkor már el tudta mondani, hogy öt mért bántotta annyira az, hogy neki beszóltak.” (harcos)

„Egy fiatalemberhez kötödik egy sikertörténetem, aki nagyon rosszul érezte magát az iskolánkban... ha néha bejött... érted, mire célzok?! Egy másik iskolából jött át, csúfolták az új iskolában, nem, nem szeretett járni, és akkor mindig hiányzott. Ezt követöen ugyebár a szociális munkás mit tehet, kimegy családot látogatni, beszélget a gyerekkel, hogy miért nem jön iskolába, beszélget a szülövel. Kimentünk a családsegitös kollegával is többször hozzájuk és folyamatosan tünödtünk, hogy mit kezdhetnénk ezzel a fiatalemberrel. Megküldtük mindenhova a jelzést, kiderült, hogy azért jött el a fiú a másik iskolából, mert ott megszünt az osztálya, de a végén nagy nehezen sikerült azt elérni, hogy visszamehessen az iskolájába. Utánkövettük, ott már szeretett lenni, nem csúfolták, nem bántották, mint az új közegben [...] egy cigány kisfiúról van szó és csúfolták, és akkor sikerült öt visszajuttatni az úgymond idézöjelesen a régi befogadó közösségébe, ahol már jól érezte magát. Egy jó képességü kisfiúról beszélünk, aki utána már eredményesen tudta zárni a nyolcadikat, jelentkezett továbbtanulni is." (magabiztos)

„Szerintem az is pozitív, kijönnek egy 45 perces óráról és ugyebár nekem mindig úgy volt az irodám, hogy lent van a földszinten, és soha nem volt becsukva az ajtó, ha nem volt bent velem kliens [...] mindig-mindig nyitva áll az ajtóm elöttük. Van, hogy tízen ott vannak, egymással beszélgetnek és az az első, hogy bejönnek és akkor »Szia... mi újság? Hogy vagy? " - megkérdeznek engem is. Tehát nem is feltétlenül azért jöttek be, hogy problémáik vannak, hanem maga az, hogy bejöhetnek egy felnötthöz, és már ez nekik ad valamit, egy pluszt ad nekik, hogy velem beszélgetnek." (színes egyéniség)

„A gyerekek abszolút megadták a tiszteletet... el is mondták, kifejezték a szeretetüket irányomban. Volt egy kis faliújságom, volt a kis papír... az a jegyzetlap, mindig elvettek egyet az asztalomról, és akkor mindig írtak kis kedves üzeneteket. Úgyhogy teljesen pozitív volt, a faliújságra meg kiakasztották. Ez nekem is pozitív visszajelzés volt, hogy ha nem is mindig feltétlenül a problémáikban segitek, de ott vagyok és tudják, hogy számithatnak rám és jólesik nekik, hogy van ott valaki." (sokoldalú)

„,...voltak olyan helyzetek, amikor ugye a gyermek eljött úgy iskolába, hogy étel nélkül, hogy tetves volt stb. Ezt a családgondozó, aki a faluban végzi ugye ezeket a teendöket, nem feltétlenül látja, ami az iskolában van. Így ugye én ott voltam, közvetlenül közöttük, még sokszor nem is kellett, hogy jelezzen a pedagógus, mert észrevettem. És akkor felvettem a kapcsolatot a gyerekjóléti szakemberrel, és együtt mentünk ki családot 
látogatni, és megnéztük, hogy mik a lehetöségeik azoknak a családoknak, akiknek pl. semmilyen bevételük nincs." (rátermett)

„Szemészet volt, ortopédiai és ugye a szemészet nagyon jó volt, mert a hátrányos helyzetü gyerekeket próbáltuk úgymond kiszürni, hogy öket vigyük. Elvittük öket, és ugye anyagilag is, tehát egy szemüveg nem olcsó és ebben is tudtuk öket segíteni. Tehát inkább ilyen dolgok voltak az én munkámban." (lelkiismeretes)

„,...édesanya és édesapa is hát konkrétan értelmi fogyatékosok, plusz olyan körülmények között élnek, ami nem megfelelö szerintem a gyerekek számára. Úgyhogy próbáltuk ugye a családban tartani öket, de ezen változtatva [...] az értelmi akadályozottság miatt speciális volt a helyzet, ilyenkor máshogy kell életvezetési tanácsot adni, kihivás, hogy hogy értesd meg, hogy konkrétan a mosógépbe nem elég, hogy berakom a ruhát, kéne valami mosószer is bele vagy akármi... Tehát eljártam akkor rendszeresen hozzájuk, mert láttuk, hogy ha megmondták nekik, hogy mit csináljanak, akkor tudták csinálni, csak ugye maguktól nem jöttek rá, de attól a gyerekeikhez és egymáshoz is nagyon ragaszkodtak... utána tisztábban jártak a gyerekek, ...ez nem mindegy, nagyon nem mindegy a befogadásuknál, ki szeret mellettük ülni, velük játszani...” (szuperhős)

„Sajnos sok gyerek nem kapja meg otthon azt a figyelmet, amit ö igényelne. És azért van rám szüksége, hogy valakivel beszélhessen. Esetleg olyan dolgokban próbáljon meg tanácsot adni, amiben igazából a szülőnek kellene. Továbbtanulásnál volt ilyen például, hogy nem tudták otthon megbeszélni, hogy ök mik szeretnének lenni, vagy milyen lehetöségek közül választhatnának. És akkor ugye leültünk az internet elé és megbeszéltük, hogy ki miböl áll jól, ki miböl jó, ki miböl gyenge, és akkor ahhoz mérten úgy felhoztuk, hogy ki mire képes, hogy mit tud megengedni a pénztárcájuk, utazni, bent lakni kollégiumban hol tudnának. Ezekben is nagyon sok segitséget nyújtottunk. ...az anyagi részen túl, legalább olyan hátrány, hogy nem kapnak annyi figyelmet a gyerekek." (szines egyéniség)

„Volt egy kisfiú... folyamatosan, nagyon problémás volt a magatartása, állandóan verekedett, állandóan csúnyán beszélt. Tudni kell, hogy nagyon rossz körülmények között él. Anyukának mindenre van ideje, csak rá nincs, el van foglalva a fiatal fiúkkal meg stb. Ugye a gyerekböl így jön ki, hogy valaki figyeljen rá... segélykiáltás, ennyi az egész. Ö az elején nem volt nyitott rám, egyáltalán nem. Mondtam: márpedig kötelezö jönni! Öneki konkrétan minden délután, kötelező volt jönni hozzám beszélgetni. És ahogy a gyerek szépen lassan megnyilt, ahogy próbáltuk ezt az egészet, átneveléssel, bizalommal, megerösitö tanácsokkal próbáltam megértetni, hogy a viselkedése nem megoldás, gondolkozzon, ezzel neki mivel jobb. És jó hatással volt rá, tudom, hogy nem a szavak, a lelki fröccs, hanem a kötödés, a bizalmi kapcsolat, ami kialakult köztünk és elkezdett akarni változni. És neki is megváltozott a magaviselete. Meg ugye, ahogy kiderültek a dolgok, én közvetítettem a dolgokat, ahogy lehetett, akkor a tanárok is már másképpen kezdtek el rátekinteni." (magabiztos)

A szociálpolitika sikeres hétköznapi megvalósítóiként, iskolai szociális munkásként hatókörük jóval az iskola falain túl is terjedt. A fenti esetekből kiolvasható, hogy akadtak teendőik a gyermekek problémamegoldó képességének, konfliktuskezelő képességének, indulatkezelésének, stresszoldásának vonatkozásában, alakítva ezzel közvetve vagy közvetlenül az iskolai kapcsolataikat, érzelmeik kezelését, megélését és kimondását, mely 
tényezők mindegyike fontos a nehézségeik ellenére való boldogulásuk, rezilienciájuk alakulása szempontjából. Azonban a szemléltetett interjúrészletek rávilágítanak arra is, hogy a gyermek iskolai környezetében játszódó személyiségbeli és társas kapcsolati változások mellett, az iskolai szociális munkások sikertörténeteikben, minden esetben EGYÜTTmüködve a pedagógussal, családsegítővel, szürővizsgálatokat végző egészségügyi szakemberekkel érték el az adott gyermek/család szükségleteihez mérten legoptimálisabb eredményt, a segítő munkavégzés során. Az ilyen esetek befejezésekor több megszólaltatott interjúalanyunk elégedett sóhajjal így fejezte be a válaszát: „,...úgyhogy ez, megoldódott!”

„A szakmaközi együttmüködéshez tehát minimálisan az szükséges, hogy a különböző szakmák képviselői együtt találják ki, hogy mit lehetne/kellene tenni egy adott, konkrét ügyben, hogy közösen tüzzenek ki célokat és tervezzék meg a közös munkát és döntsenek a további beavatkozások tekintetében, hogy a továbbiakban folyamatosan tartsák egymással a kapcsolatot, hogy rendszeresen találkozzanak egymással, hogy újra és újra kiértékeljék az eseményeket, elemezzék egymás tapasztalatait, hozzanak újabb és újabb döntéseket. A hosszabb időtartamú, komplex szemléletü, folyamatos stáb-team munka vezethet el a tényleges szakmaközi tevékenységhez." (Budai 2017: 61-62)

A korábban elemzett interjúrészletekben megjelentek a válaszadó szociális munkások által leggyakrabban alkalmazott területek, módszerek. Válaszaik alapján többnyire egyéni esetkezelést, esetgondozást végeztek, családgondozást, együttműködve osztályfönökökkel, szaktanárokkal, azonban a pedagógusok csoportjával, a tantestületi közösséggel, annak fejlesztésével, vagy az iskola mint helyi társadalmi közösség fejlesztésével összefüggő feladatok, tevékenységek nem jelentek meg, az alábbiakban elemzett sikerekről és kudarcokról szóló válaszaikban sem.

Az intézményi müködést, a szervezeti kapcsolatokra is hatást gyakorló közösségfejlesztő munka, szintén fokozhatná a szakmaközi együttmüködés hatékonyságát pedagógusok és szociális munkások között.

Az érdemes és érdemtelen szegénység szociálpolitikai dilemma analógiájára, ma már nem az a kérdés, hogy jelen kell-e lennie az iskolában a segítőnek, azaz nem lehet kérdés, hogy „érdemes-e” arra a szociális munkás, hogy teret kapjon az iskolában. Sokkal inkább kérdés, hogy mit és hogyan tegyen annak érdekében, hogy tevékenysége a pedagógiai munkát olyan speciális módon egészítse ki a szociális munka módszereinek, eszközeinek célzott alkalmazásával, amellyel valós egyéni és közösségi szükségletekre reflektál.

Az idézett kutatási eredmények és a fejlődést akadályozó jelenségek, mint például az iskolai agresszió terjedése, a társadalmi kapcsolatok és az iskolai közösségek zavaraira utalnak. A tanulmány további részében olyan újfajta szemléletet követö jó gyakorlatokat, illetve adaptálható módszereket mutatunk be, melyek segítségével utat mutathatnak a szakemberek a serdülök, fiatalok számára önmaguk megismeréséhez, ezáltal társadalmi kapcsolataik sikeresebb müködtetéséhez.

A bemutatott két program közös pontjai: gyermek, gyermekek boldogulási esélyeinek növelése. Mindkét program a gyermekeknek, gyermekekért íródott, pedagógusokat, gyermekvédelmi szakembereket célozva, akik vezetik őket a „boldogulás útján”. 


\section{Hazai megoldások, jó gyakorlatok rövid ismertetése: a gyermeki szükségletekre adekvát válaszok társadalmi, egyházi szervezetekkel összefogásban}

$K A ́ S Z P E M{ }^{4}{ }^{4}$ a gyermek és fiatal belsö épitészete módszerének rövid bemutatása

„A KÁSZPEM ${ }^{\circledR}$ egy olyan csoportmódszer és pedagógiai rendszer, melyet Kothencz János hívott életre és az ÁGOTA ${ }^{5}$ Alapítvány tesz közzé, azzal a céllal, hogy a segítségre szoruló gyermeket és fiatalt segítő - saját érzékenységét alapul véve -, nevelő hozzáállással vezethesse a gyógyulás útján. A módszer alapvetően pedagógiai természetü, de terápiás jelleggel is bír." (Kothencz, Kothenczné Osváth et al. 2009: 33)

A módszertan 7 alappilléréhez, kidolgozója rövid, közép- és hosszú távú célokat rendelt, kijelölve a tematikus csomópontokat és a gyermekcsoportokban lévők egyéni és társas szükségleteihez mindenkor igazítandó területeket, melyek feldolgozása során az elvárt, leginkább célravezető nevelöi attitüdök is meghatározásra kerültek. (Kothencz et al. 2009: 50-57)

Sávai professzor (2009) megfogalmazásában: „A KÁSZPEM® csoportfoglalkozások Anonimizált Jegyzőkönyvei sokoldalú és nagyon jól követhető fejlődési vonalat vázolnak elénk arról a belső építészetről, amelyet ez a Módszer jelent. Nem látványos, tetszetős programokban oldja fel a gyermekekben - néha kőkeménnyé gyült - szomorúságot, (haragot?). Nem feledteti magukat, nem igyekszik velük elhitetni, hogy »amúgy « minden rendben és »legyenek hálásak«... Lényegesen többről van szó: felnőtté, a maguk életének pozitív formálójává válásról van szó. Megtanulnak nem elvárni, hanem a maguk valóságából építkezni. Ez a KÁSZPEM®.” (Sávai 2009: 18)

A program alappilléreiként említik a módszer kidolgozói: 1. bizalomkép; 2. interperszonális kapcsolatok; 3. normák és vezérfonalak; 4. traumafeldolgozás; 5. kiszolgáltatottságérzet kezelése; 6. önrendelkezés; 7. teljesítményhez való viszony, jövőkép (Kothencz et al. 2009).

„A csoportfoglalkozások úgy mozdítják elő a személyiség fejlődését, hogy közben növelik annak szociális kompetenciáját, a közösségbe, társadalomba való beilleszkedési képességét is." (Eisenbach 2009: 26)

„A módszer nem feledtetni akarja a múltat... Tudatosítja életüket, amit nem szégyellniük kell, hanem feldolgozni." (Sávai 2009: 19)

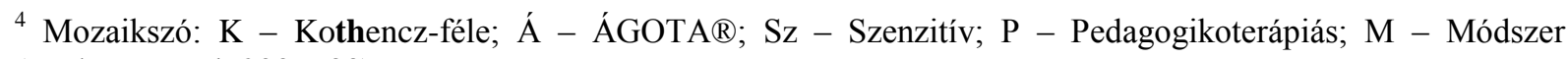
(Kothencz et al. 2009: 33).

${ }^{5}$ ÁGOTA $囚$ : Állami Gondoskodásban Élő és Veszélyeztetett Fiatalok Támogatásáért Alapítvány, mely a hazai és nemzetközi gyermek- és ifjúságvédelem gyakorlatába és rendszerébe, valamint a társadalomba hivatott beültetni a módszert.
} 


\section{Mindenhol Otthon - pedagógusoknak szóló készségfejlesztő, képességfejlesztő programcsomag felhasználásának lehetőségei}

A Mindenhol Otthon Közhasznú Alapítvány által müködtetett program jelmondata: „Zsebedben a világ, ha tudod, ki vagy és mit akarsz. ",

Az alapítvány munkatársai által kinyilatkoztatott küldetésük, hogy a gyermekeket és az öket körülvevő felnőtteket, a szocializáció során célzottan támogassák. Olyan módszerekkel szolgálnak a gyermekek fejlődésében közremüködő szülők, pedagógusok számára:

- amelyek a gyermeki énkép formálódásában nyújt segítséget, mely

- önelfogadáson és reális önértékelésen alapul.

- A családi értékek tiszteletben tartásával felruházza a gyermekeket és fiatalokat hatékony önérvényesítéssel,

- fejleszti szociális érzékenységüket, empátiájukat és toleranciájukat,

- $\quad$ ezáltal a társadalom sikeres, boldog és felelős tagjaivá teheti őket (Segal 2010).

Az alapítvány célja, hogy olyan, az iskolai tananyagból hiányzó készségekre adjon innovatív gyakorlati ötleteket, módszertani támaszokat a pedagógusoknak, illetve szülőknek és gyerekeknek, amelyek alkalmazásával a gyerekek közelebb kerülhetnek a felnőttek világához és fordítva. Hitvallásuk szerint nem a 18. életév betöltése tesz képessé egy gyereket a sikeres felnőtté válásra, hanem épp az azt megelőző 18 évben elsajátított készségek és ismeretek (Segal et al. 2011).

Pedagógusoknak szóló programjukban az óvodás és kisiskolás korcsoporthoz tartozó gyermekek számára összeállított gyakorlatok cél- és ismeret, képességrendszerén túl módszertani útmutatót is nyújt a tanórai és iskolai keretek között történő megvalósításhoz.

„Mindenhol jó, de legjobb otthon” - szól a jól ismert közmondás. A stabil identitástudattal bíró ember, akinek vannak gyökerei, amelyek láthatatlanul is biztonsági hálót fonnak köré, a világ bármely részén képessé válik a helytállásra a globalizáció elönyeivel áldott és hátrányaival terhelt, felgyorsult világban éppúgy, mint a tradicionális, természettel máig szimbiózisban, egységben müködő társadalom közegében. Az óvodás- és kisiskoláskorú gyermekek nyitottságára, természetes kíváncsiságára, a gyermeki személyiségre jellemző egocentrizmussal is számoló, a kisgyermekkori mágikus gondolkodásra is alapozó első kötet tananyagtartalmainak játékos elsajátítása során teszik meg a gyermekek a felnőtt által irányított „repülő szőnyegen” a nagy utat önmagukból, önmaguktól egészen közeli és távoli embertársaik felé. A kognitív képességeken túl a szociális, társas készségeket, képességeket is hatékonyan fejlesztő modulok alkalmassá teszik a gyermeket a multikulturális társadalmak sokszínűségének elfogadására, hidat építve a különbözőségek és azonosságok, a többség és kisebbség között, növelve ezzel szociális érzékenységüket, illetve tudatosítva társadalmi felelősségüket maguk és embertársaik iránt.

A Mindenhol Otthon másságot, kulturális sokszínüséget megismerni és elfogadni tanító második kötetének útmutató tartalmi elemei, azon túl, hogy egy nagyobb korosztály formálását segíti a szisztematikusan, logikusan felépített tananyagfüzérrel, újabb hatalmas lehetőség szülőknek, pedagógusoknak és gyermekeknek egyaránt ahhoz, hogy valóban „otthonossá" váljék számukra a világ. Mit is jelent az otthon? Az - napjainkban, amikor

\footnotetext{
${ }^{6}$ http://mindenholotthon.hu, utolsó látogatás ideje: 2018. június 20.
} 
semmi sem állandó, csak a változás - mindenkinek mást. Hogyan lehet mégis megélni az állandóságot otthonainkban, leginkább saját belsö világunkban? Az „otthonosság” érzésvilágának megtapasztalásával, melyet éljünk palotában vagy kunyhóban, a Föld északi vagy déli féltekéjén a befogadás és elengedés örök körforgásának bármely ciklusában, minden esetben jellemez a biztonság, szeretet, feltétel nélküli elfogadás, méltányosság, tisztelet, odafordulás, törődés, figyelem. Ezek azok a láthatatlan szálak, melyek az élet viharaiban is visszahúzzák a gyökeréhez az Embert és a Földön megtartják. Ebben az értelemben az otthon és az „otthonosság” érzésével járó felelősség túlmutat a családi ház falain, kiterjed másodlagos szocializációs színtereinkre, így a kortárskapcsolatokra, iskolára is.

A kidolgozott gyakorlatgyüjtemény a prepubertás-, pubertáskorban lévő éppen a felnőtté válás első lépcsőfokán járó, saját gyermeki határaikat bontogató, „lázadó” korosztálynak szól.

Segítséget nyújt a gyermekeknek és az otthonosságérzetük alakításán fáradozó felnőtteknek is abban, hogy felvérteződjenek mindazokkal az ismeretekkel, készségekkel és képességekkel, melyekkel IGAZODNI tudnak. Mindenhez. Interaktív, játékos formában juttathatják őket tanáraik, mentoraik mindazon megtapasztalásokhoz, melyekkel a természeti és társadalmi környezetükben tudatosan mozoghatnak, saját jóérzésük szerint alakítva, oltalmazva azt. Megvédve ezzel a tudatossággal a természeti környezetet, a társadalmi környezetükben élöket és Önmagukat... legyen szó testi-lelki-mentális egészségük megőrzéséröl, a devianciák sikeres elkerüléséről vagy a világháló áldásos, avagy veszélyes hatásairól.

Egyéni és társadalmi érdek is, hogy a növekvő generáció vezetve legyen az önismeret útján. Hiszen amíg nem ismerik önmagukat gyermekeink, mások megismerésére, elfogadására sincs valós esélyük (Homoki 2013).

„Az ember kiteljesedése abban áll, hogy képes boldoggá tenni másokat.” (Sávai 2009: 20)

Az iskolai életviláguk azonban csak akkor válhat „otthonossá” számukra, ha a megismerésből és elfogadásból fakadó biztonságérzet képessé teszi őket a mindennapok nehézségeivel való megküzdésre, rugalmasságra (resilience). A gyermeki reziliencia fejlesztési lehetőségeit vizsgáló kutatások (Masten 2007; Ungar et al. 2013; Homoki 2014, 2016) eredményei alapján a gyermek életben való sikeres boldogulásának előfeltétele a családi gyökerek ismerete, a pozitív iskolai környezet, a valós, pozitív kapcsolatok kialakítása kompetens felnőttekkel, tanárokkal és kortársakkal, a hit megélésének képessége, a problémamegoldó képesség, a jövőtervezés, újratervezés képessége.

Mindezen területeket érintik a modulok, melyek tapasztalatainak együttes megélése aktivitás, öröm a gyermekeknek és a velük foglalkozó szakembereknek (szociális munkásoknak, szociálpedagógusoknak, közösségfejlesztőknek, pedagógusoknak) egyaránt.

A fenti programok bemutatásának célja rávilágítani arra a lehetőségre, miszerint az egyéni „belső-” és környezeti (külső) „építészet - szépítészet” (Kothencz 2009) célját szolgáló módszerek alkalmazására való képessé tétel beilleszthető a gyakorlatorientált képzési programokba a pedagógusképzés, a szociális munka, szociálpedagógia, szociális és pedagógus-továbbképzések anyagába, az iskolai szociális munka szakirányú továbbképzés területén is. 


\section{Befejezés}

Befejezés helyett, ígéretes a folytatás. Ahol ez idáig még nem voltak adottak a feltételek az 1997. évi XXXI. számú, A gyermekek védelméről és gyámügyi igazgatásról szóló törvény (Gyvt.) által 2016. január 1-jétől a gyermekjóléti szolgáltatások keretében biztosítHATÓ iskolai szociális munka végzéséhez, a jogszabályi változásokat követően 2018 szeptemberétől az ország valamennyi család- és gyermekjóléti központja kötelezően ellátandó szolgáltatásként, 1000 fő tanulónként 1 fő iskolai szociális munkás alkalmazásával biztosítja a feladatvégzést.

2018 szeptemberétől az iskolákban megjelenő szociális munkásoknak, segítőknek a lendületes kezdetre kell törekedni, személyiségükkel, szakmai készség- és képességrendszerük szerint a szakmai és szakmaközi együttműködés, a gyermeki szükségletorientáció alapelveinek figyelembevételével, újszerü, kiegészítő szolgáltatással sokat tehetnek a gyermeki sorsok, életutak pozitív irányú formálásában.

Alkalmasak lehetnek a gyermekek testi, lelki, szellemi, szociális jóllétének kedvező alakításához a bemutatott programok, melyek készség- és képességrendszerekre, személyiségbeni és környezeti tényezőkre gyakorolt hatásaikkal a gyermeki reziliencia fejlődését eredményezik, felvértezve ezáltal a gyermekeket a hosszan tartó nehézségeik ellenére való megküzdés képességével, ezáltal teret engednek és utat mutatnak a gyermekeknek, sikeres fiatal felnőttlétük megalapozásában.

Mindkét ismertetett program elsődleges célkitüzése a gyermeki boldogulás elősegítése, felhasználva a gyermeki személyiség belső erőforrásait, alapozva a gyermek környezetében, közösségeiben fellelhető támogatásokra.

Napjainkban iskolatársadalmi problémaként határozhatjuk meg a bullying, az iskolai erőszak, kortársbántalmazás jelenségét. Azokban az iskolákban, ahol az iskolai agresszió jelei már egészen kicsi gyermekek körében mutatkoznak, közös érdek a KÖZÖSSÉG és ezen belül az EGYÉNek - Kothencz János szavaival élve - „, belsö (sz)épitészete”.

Mindez valós szakmai együttmüködést feltételez, a programalkotók nyitottsága az iskolák „zaklatásfelelősei”, a család- és gyermekjóléti szolgálatoknál alkalmazásban lévő iskolai szociális munkások, pedagógusok felé megfelelő alapot jelent a programok kidolgozóival való kapcsolatfelvétel kezdeményezésére, együtt gondolkodásra.

Ahogyan a halmozottan hátrányos helyzetü térségben készített kutatás adatai mutatták, ezekre és az ehhez hasonló programhatásokra nagy szükség van, hiánypótlóak a gyermekközösségekben, hiszen - ahogyan az egyik interjúalany elmondta - néha úgy érzik, már az egészen kicsi gyermekek is, hogy bezáródott minden ajtó és már el is fogyott az út a lábuk alól... hogy ez mennyire nincs így, az alábbi, iskolai szociális munkásokkal folytatott interjúinkból idézett részletek zárszóként érzékeltethetik azt:

„,...mindig-mindig nyitva áll az ajtóm elöttük!”

„,...akkor a tanárok is már másképpen kezdtek el rátekinteni!”

„,...egy pluszt ad nekik, hogy velem beszélgetnek!” 
„,...az anyagi részen túl legalább olyan hátrány, hogy nem kapnak annyi figyelmet a gyerekek."

„,...tisztábban jártak a gyerekek, ez nem mindegy, nagyon nem mindegy, ki szeret melléjük ülni, velük játszani!"

\section{Irodalomjegyzék}

BAUER B. (2011): A kulturális szemlélet spiráljai - a magyar fiatalok kulturális és szabadidős szokásainak különbözőségei az ezredfordulón. In BAUER B., SZABÓ A. (szerk.): Arctalan (?) nemzedék - Ifjúság 2000-2010. Belvedere Meridionale Kiadó, Szeged. 221-249.

BÁNYAI E. (2000): Az iskolai szociális munka és lehetőségei az ezredfordulón Magyarországon. Háló, 8. 3-5.

CEGLÉDI T. (2012): Reziliens életutak. Szociológiai Szemle, 22(2). 85-110.

CICCHETTI, D., COHEN, D. J. (eds.) (2006): Developmental Psychopathology. Vol. 3: Risk, Disorders and Adaptation. Hoboken: John Wiley \& Sons. http://eu.wiley.com/WileyCDA/WileyTitle/productCd-0471237388.html (utolsó letöltés: 2015. 11.25.).

CSAPÓ B. (2003): A képességek fejlődése és iskolai fejlesztése. Akadémiai Kiadó, Budapest.

FÁBIÁN R. (2011): Egészségkárosító magatartások a magyar fiatalok körében. In BAUER B., SZABÓ A. (szerk.): Arctalan (?) nemzedék - Ifjúság 2000-2010. Belvedere Meridionale Kiadó, Szeged. 209-219.

FORRAY R. K. (2004): „Ebbe a dolgozatba beleírtam a lelkemet”. Iskolakultúra, 8. 130-140.

FORRAY R. K. (2013): Az idő fogságától szabadon. Akadémia Kiadó, Budapest.

GAZSÓ T. (2013): Munkaerő-piaci helyzetkép. In SZÉKELY L. (szerk.): Magyar Ifjúság 2012 - Tanulmánykötet. Magyar Közlöny Lap- és Könyvkiadó, Budapest. 127-152.

HOMOKI A. (2012): A gyermek- és ifjúságvédelmi felelősök munkavégzéséhez kapcsolódó dilemmák. Educatio, 21(1). 151-158.

HOMOKI A. (2013): Előszó. Mindenhol Otthon. Mindenhol Otthon Közhasznú Alapítvány, Gyula.

HOMOKI A. (2014a): A gyermekvédelmi gondozottak rezilienciavizsgálata a Dél-Alföld és az Észak-Alföld régióban. Letölthetö: https://www.academia.edu/.

HOMOKI A. (2014b): Az iskola és a gyermekvédelmi intézmények rezilienciát elősegítő hatásai. In CEGLÉDI T., GÁL A., NAGY Z. (szerk.): Határtalan oktatáskutatás Tanulmányok a 75 éves Kozma Tamás tiszteletére. CHERD Hungary, Debrecen. 45-57. 
HOMOKI A. (2016): A reziliencia recepciója a hazai neveléstudományi kutatásokban. In PUSZTAI G., BOCSI V., CEGLÉDI T. (szerk.): A felsőoktatás (hozzáadott) értéke. Közelítések az intézményi hozzájárulás empirikus megragadásához. Partium Könyvkiadó Új Mandátum Könyvkiadó, Nagyvárad-Budapest. 78-90.

KOTHENCZ J., KOTHENCZNÉ OSVÁTH V. et al. (2009): Rólunk... értünk... II. Családból kiemelt gyermekek és fiatalok pedagógiája. ÁGOTA® Alapítvány, Szeged.

MAKAI É. (2003): Szétszakadt és meg nem font hálók. Okker Kiadó, Budapest.

MAROS K., TÓTH O. (2002): Az iskolai gyermekvédelem helyzete. Kapocs. 4-14.

MÁTÉ ZS., SZEMELYÁCZ J. (2009): Az iskolai szociális munka kézikönyve. INDIT Közalapítvány, Pécs.

MÁTÉ ZS. (2015): Iskolai szociális munka 2015. Esély, 4. 77-96.

PUSZTAI G. (2004): Kapcsolatban a jövővel. Valóság, XLVII/5. 69-84. http://www.valosagonline.hu/index.php?oldal=keres\&tenyezo=5.\&kerkedes=23

PUSZTAI G. (2011): A láthatatlan kéztől a baráti kezekig. Hallgatói értelmező közösségek a felsőoktatásban. Új Mandátum Könyvkiadó, Budapest.

SCHOFIELD, G., BEEK, M. (2005): Risk and Resilience in Long-Term Foster-Care. British Journal of Social Work, 35(8). 1283-1301.

SEGAL H. (2010): Mindenhol Otthon 1-2. - Légy magabiztosan önmagad a világban.

Otthonodba Hozzuk a Világot Alapítvány, Budapest.

SOMLAI P. (2011): Nemzedéki konfliktusok és kötelékek. In BAUER B., SZABÓ A. (szerk.): Arctalan (?) nemzedék - Ifjúság 2000-2010. Belvedere Meridionale Kiadó, Szeged. 25-37.

SOÓS ZS. (2017): Szociális ismeretek oktatása a pedagógus BA képzésekben. Szerk.: MÁNDI N. Szociálpedagógia - Diskurzusok, horizontok 3-4. 24-39.

SUSÁNSZKY É. (2011): Ifjúság és egészség = Egészséges ifjúság? In BAUER B., SZABÓ A. (szerk.): Arctalan (?) nemzedék - Ifjúság 2000-2010. Belvedere Meridionale Kiadó, Szeged. 143-159.

VARGA J. (2015): A közoktatás indikátorrendszere 2015. MTA KRTK KTI, Budapest. 